\title{
Care for children under six months at domicile: primiparae mother's experience
}

\author{
Cuidado à criança menor de seis meses no domicilio: experiência da mãe primípara
} Cuidado al niño menor de seis meses en el domicilio: experiencia de la madre primípara

\begin{abstract}
Maria Lucíola Vasconcelos ${ }^{1}$ (1)
Vera Lúcia Mendes de Paula Pessoa ${ }^{1}$ (D)

Edna Maria Camelo Chaves ${ }^{1}$ (D)

Mardênia Gomes Vasconcelos Pitombeira ${ }^{1}$ (1)

Thereza Maria Magalhães Moreira ${ }^{1}$ (iD

Monalisa Rodrigues da $\mathrm{Cruz}^{2}$ (D)

Anna Laurita Pequeno Landim ${ }^{3}$ (D)
\end{abstract}

1. Universidade Estadual do Ceará.

Fortaleza, CE, Brasil.

2. Escola de Saúde Pública do Ceará.

Fortaleza, CE, Brasil.

3. Hospital São Carlos. Fortaleza, CE, Brasil.
Corresponding author:

Maria Lucíola Vasconcelos.

E-mail: luciolavasconcelos@yahoo.com.br

Submitted on 09/26/2018.

Accepted on 02/09/2019.

DOI: 10.1590/2177-9465-EAN-2018-0175

\section{Abstract}

Objective: To understand how the primiparous mother exercises maternal care of the child under six months of age at home. Method:Descriptive research with a qualitative approach. A research was carried out at the Primary Health Care Unit in Fortaleza/ CE, between the months of May and June 2017, with 20 primiparous mothers. It was used thematic content analysis to analyze the data. Results: Through the organization of the speeches, we obtained the category Maternal Experience in Care. It was noticed that fear, insecurity and doubts were present in the daily life of the interviewees, interfering with care such as bathing and holding the baby; the cleaning of the umbilical scar was ceased after the stump fell; babies slept on their stomachs; pain and stress contributed to the failure of lactation; cleaning of the umbilical stump was ceased after its fall; babies slept in the ventral position; previous experience in caring for younger siblings influenced maternal care. Conclusion and implications for practice: It was understood that the orientations made by the nurses are fundamental for the qualification of the primiparous mothers in the care of the child.

Keywords: Primary Health Care; Newborn; Childcare.

\section{Resumo}

Objetivo: Compreender como a mãe primípara exerce o cuidado materno ao filho menor de seis meses no domicílio. Método: Pesquisa descritiva com abordagem qualitativa, realizada em uma Unidade de Atenção Primária à Saúde, em Fortaleza/CE, nos meses de maio e junho de 2017. Participaram 20 mães primíparas. Utilizou-se análise temática de conteúdo para análise dos dados. Resultados: Da organização dos discursos, obteve-se a categoria Experiência Materna no Cuidado. Percebeu-se que sentimentos de medo e insegurança estavam presentes no cotidiano das entrevistadas, interferindo nos cuidados como banhar e segurar o bebê; a limpeza da cicatriz umbilical era cessada após a queda do coto; bebês dormiam de bruços; dor e estresse contribuíram para insucesso da lactação; experiência prévia no cuidado aos irmãos mais novos influenciava o cuidado materno. Conclusão e implicações para a prática: Compreendeu-se que as orientações realizadas pelos enfermeiros são fundamentais para qualificação das mães primíparas na assistência ao filho.

Palavras-chave: Atenção Primária à Saúde; Recém-Nascido; Puericultura.

\section{RESUMEN}

Objetivo: Comprender como la madre primípara ejerce el cuidado materno al hijo menor de seis meses en el domicilio. Método: Investigación descriptiva con abordaje cualitativo. Se realizó una investigación en Unidad de Atención Primaria a la Salud, en Fortaleza/CE, en los meses de mayo y junio de 2017 con 20 madres primíparas. Se utilizó análisis temático de contenido para análisis de los datos. Resultados: Através de la organización de los discursos se obtuvo categoría Experiencia Materna en el Cuidado. Se percibió que miedo, inseguridad y dudas estaban presentes en el cotidiano de las entrevistadas, interfiriendo en los cuidados como bañarse y sostener al bebé; la limpieza de la cicatriz umbilical era cesada después de la caída del coto los bebés dormían de bruces; dolor y estrés contribuyeron al fracaso de la lactación; la limpieza del coto umbilical era cesada después de su caída; los bebés dormían en la posición ventral; experiencia previa en el cuidado a los hermanos más jóvenes influía en el cuidado materno. Conclusión e implicaciones para la práctica: Se comprendió que las orientaciones realizadas por los enfermeros son fundamentales para la calificación de las madres primíparas en la asistencia al hijo.

Palabras clave: Atención Primaria de Salud; Recién Nacido; Cuidado de los Niños. 


\section{INTRODUCTION}

The birth of a child produce mixed feelings that need to be recognized and valued not only by the mother, but also by all those involved in its care, since these feelings may result in conflicts generated by insecurity, fear and doubts before the situation imposed by the child's arrival, especially when this is the first child. For this reason, the prenatal becomes a favorable space for the professional to provide orientations, suggest, observe and interact with the future mother, in order to all their doubts are resolved and enlightened in timely.

The possibility of expressing fears and doubts about the maternity; of being heard on the uncertainties generated by the new experience; of being advised on ways to demonstrate love and affection to the baby during the prenatal contributes to the development of a positive link between mother and child. ${ }^{1}$

The consultation of the childcare actuate in the promotion of health and early detection of problems, in addition to favor care in an individual manner, prioritizing the well-being of the child, in order to ensure adequate growth and development in physical, emotional and social aspects. ${ }^{2}$

Moreover, understand the lived experiences and experiences of the primiparous mother, when takes care of the child, is a way of knowing and valuing the existing relationships along with the health team by promoting the integral care of the child under six months, at home.

Therefore, the actuation of the multi professional team, with emphasis on the nurse's action, alongside the pregnant and puerperal women is fundamental to integrate the newborn to healthcare services, extend the conducts besides the basic unit, by encouraging mothers to share their doubts and difficulties with respect to the safe care practices to the care of children.

It is clear that the care of the baby requires many hours of dedication. Then, the support provided to the woman represents valuable contribution, by collaborating to reduce the workload. The Family Health Team can identify a support network that can offer support for the mother, involving the own members of the family, such as grandparents, uncles, friends and neighbors.

In this aspect, it is worthy to emphasize that the support networks have an important role in the mothers' life who work outside the home, since the four months of maternity leave granted by the labor legislation in Brazil does not include the time necessary for the intense and continuous maternal care required by the child at the beginning of the life. ${ }^{3}$ In that way, strengthening the care existing in the social relation of families and the community collaborates to a better quality of life and more health to their members. ${ }^{4}$

The interest for the theme emerged from the observation of the feelings of insecurity in the essential care of the baby, as shown by the mothers during the childcare consultation. Therefore, the following question was proposed: Which are the experiences of the primiparous mother before the care for the child under six months at home? The study has as objective to understand how the primiparous mother exerts the maternal care of the child under six months at home.
In this sense, the study is relevant, since it intends to provide mothers with subsidies for the development of the good practices of the domiciliary care of the child under six months.

\section{METHOD}

Descriptive research, with qualitative approach that allowed to know the universe of meanings, beliefs and attitudes of primiparous mothers, in relation to the care of their children, carried out in a Primary Health Care Unit (PHCU), located in the Itaperi quarter in Fortaleza city- Ceará; The referred PHCU has a vast territory of coverage with a population attended of around 9,500 families, which are assisted by six teams of the Family Health Strategy (FHS); this is also an important field of practice for undergraduate students from different higher education institutions from the capital city, where is the actuation local of the researcher, as a nurse of the FHS. This study comprises a research from a master's dissertation that addresses the care of children under six months at home, of which we extracted an analytical category to develop the present article.

The research participants were identified among the mothers with children under six months regularly monitored in the Childcare consultation. The data collection occurred during May and June 2017.

Regarding the quantitative research participants, it was initially estimated that, this number would be around of 20 mothers, but that might be changed due to the discursive content and recurrence of meanings perceived. Therefore, the step of achieving new discourses was closed with the participation of 20 mothers.

Primiparous mothers with children at ages ranging from zero to six months had been included in the study monitored by the Childcare Program and carried the prenatal in the health institution where the research was developed. Primiparous mothers with premature babies, of low birth weight, with any syndrome or malformation that needed follow-up in the specialized service were excluded.

In collecting information, the semi- structured interview was used, which was initiated with the interviewees' identification, including age, educational level, marital status and profession.

Following this stage, the interviewees were approached from the following guiding questions: How are you taking care of your child at home? What would you like to know to take good care of your child? It is important to point out that the questions, previously elaborated made possible the opening for others questionings, through the empathy and singularity of the meeting between the mother and the researcher.

The application of the interviews was initiated soon after the authorization from the research ethics committee responsible for the project appraisal; it occurred in an individual way, by the participant's acceptance. The chosen place was the service room of the researcher (nursing office), where it was possible ensuring the privacy and to preserve the interviewees' identity, we have decided on using the " $\mathrm{M}$ " initial, relating to the mother, followed by an Arabic numeral, following the sequence of 
inclusion of the same in the research (M1, M2... M20). These were clarified about the proposal and signature of the Informed Consent Form and of the Informed Consent for Adolescents. A recorder was used with the interviewees' authorization to ensure the speeches record. The time required was given for the mothers to express their doubts. After the interviews, the recordings were transcribed in their entirety, ensuring the trustworthiness of the discursive contents.

For analyzing the empirical material of the semi- structured interviews, we opted for the thematic content analysis that unfolds in the steps of pre-analysis, material exploitation or codification and processing of results/interpretation. ${ }^{5}$

The first step in the data analysis was the pre-analysis, that is, after the transcription and organization of the material, it was carried out its exploration, seeking through successive readings, and substantial content for the speeches analysis.

In the second step, the data analysis was initiated in an exploratory manner, by allowing it to arise from the speeches the units of meaning for grouping of the themes by similarity, obtaining as a result an analytical category that aims at expressing the precise description of the relevant contents throughout the text.

In the third and last step, the results treatment with the interpretation and qualitative analysis of speeches occurred, through explicit verbalizations about the questionings addressed to the mothers. Thus, it is important to clarify that the reflections and interferences presented in this study were subsidized in the scientific production whose authors dealt with questions addressed to the themes that emerged from the maternal experience in the care actions of her child during the first few months of life.

This study obtained a favorable opinion issued by the Ethics Committee of the State University of Ceará, in 05/03/2017 under the no. 66877217.8.0000.5534.748, in accordance with current legislation in the period. The ethical precepts of voluntary and consented participation of each individual were respected.

\section{RESULTS}

Twenty primiparous mothers, with children ranging from zero to six months participated in the study. The mothers 'age group, during the period of the interviews ranged from 14 to 34 years old, among them, five adolescents; $40 \%$ had complete high school; $50 \%$ lived in stable union with the child's father. The home occupation was exercised by $55 \%$ of the interviewees and $60 \%$ had family income of only one minimum wage.

The study revealed the baby's bath as one of the most difficult procedures to be carried out by the interviewees, being the feelings of fear and insecurity related to the baby's fragility and the difficulty about how to pick him, as shown in the following expressions:

[...] It needs to be very careful because he was very young and I was afraid of, I don't know, of knocking down, of [...] I had the most care, I held well insured [...] (M1).
[...] Despite I bath different than my mother taught , because my way, like this, I feel more safe bathing him otherwise[...] (M7).

[...] I stayed, I was afraid of bathing him and slip into the bath tub[...] (M1).

[...] I was afraid of falling her to the floor, I did not feel confident because she was very soft [...] (M5).

[...] Because she was very young, very soft, I was afraid of [...] do you know? [...] of using the soap and then, she slip (M9).

It was found along the testimonies that the mothers carried out the cleansing of the umbilical cord stump in an adequate way; however, those discontinued the hygiene with $70 \%$ alcohol, soon after the rupture and fall of the umbilical cord stump.

I cleaned the belly with cotton swab and with $70 \%$ alcohol until it fall (M3).

The issue, thus, of his belly l've been dealing with 70 alcohol 70, and cleaning until fall [...] (M16).

I always cleaned with cotton swab, a little cotton piece, all life when I bathed, I cleaned. And three times a day, with 70\% alcohol (M11).

Another findings of this study revealed that mothers with some experience acquaired in the care of their younger Brothers or of other children were more apt to provide care of their own child. As explained below:

Diaper change, these small easier things I had already a little practice because I have a much younger sister, I also helped my mother when my sjster was [...] She was small pequena (M7).

With my niece, that her mother left, then, I was the one with her (M14).

The speeches below show the mothers' unknown, in relation to the baby's position to sleep and to burp.

She sleeps anyway (M12).

When she got sidetrack, then she turned around and then she got scared and awoke, then I took and I placed her on her belly (M17).

My biggest difficulty is putting him to burp, I think, it is at the time to put him to burp (M19).

In relation to the practice of breastfeeding, the study ratified the mothers' low adherence and showed that certain difficulties such as incorrect handling, inverted nipples, pain and stress contributed to lack of success in breastfeeding. The following testimonies bring this perception: 
[...] The biggest difficulty was because I have not milk enough, and with 25 days, I needed to complement with a formula, because with [...] Only the breast milk did not supply (M7).

It was very difficult [breastfeed] because I had not the breast nipple (M9).

For a while, I'm not giving [the breast] doesn't it? Because it came out pus, wounded, came out blood, then, for a while I'm not giving, because if I was stressed, I stressed the child, I cried, I trembled, I was cold (M18).

I preferred to feel the pain of breastfeed her than I do not have milk to breastfeed and she gets some kind of disease (M9).

In addition, in view of the difficulties faced in the daily of the primiparous mothers in providing care of their children, it observes that the fear before the risk of the baby's sickness causes concern and suffering to the mothers, as reported in the speeches below.

When he is, as such, with fever I get too worried (M10).

Regarding when he is sick, because I don't know how to do, I get worried (M13).

It also showed by the primiparous mother that the internet is detached as an important source of research:

If I see any strange thing in him, then I go: mother, is this? This? This? Then, if the mother does not know, I go and search in the Internet [...] I see in the internet, I research very much in the internet (M4).

Then, I did not know, even having seen in, in the YouTube, doesn't is, because I search everything in the internet too (M6).

Nowadays, any doubt, that I think that, the most mothers has, search in the internet (M11).

Doubts related to the meaning associated with the baby's crying bring worry to the mothers, due to the difficulty in the decision-making about the best strategy of comfort or consolation of its child:

I have only a doubt between the crying of the sleeping and the crying of the colic, I have doubts (M6).

Sometimes, it is only a crying that he does not use to do, it brings me doubts (M7).

I don't know, thus, when he is crying, I don't know if he is feeling anything, if he wants to suck, if he is with anything, if he is hot [...] (M10).
On the other hand, some mothers recognize the babies needs through the crying manifested:

It's because, sometimes, he cries, I know his crying when he's hungry, when he is dirty, when he is hot, I know (M1).

I already identify, when he has colic, when he is naughty to sleep [...] When he is already annoyed with anything, when he is hot [...] (M4).

The change of diapers is a care reaffirmed in the maternal discourses, ensuring the baby's hygiene and well-being:

I don't leave him much with the diaper, with the same diaper, I stayed changing from instant to instant (M1).

Whenever she pees or poop I always change her diaper, I clean with moist tissue (M6).

\section{DISCUSSION}

\section{The Maternal Experience in the Care}

It is known that the experience of the maternal care is permeated by feelings of fear and insecurity that are faced by the mothers in diverse ways, in order to overcome the difficulties that arise during the exercise of the maternity, in facing with tasks never carried out before.

These difficulties may interfere in the carrying out of care of the baby, especially when it comes to primiparous mothers. On the other hand, a significant modification in the personal identity of this woman should be added to this mother's experience, and the one of becoming mother adds to those already required roles of wife and, many times, of the professional woman. ${ }^{6}$

On the other hand, the difficulties are overcome by the emotion in promoting the maternal care of the baby. The happiness during bathing in the newborn allows the mother to pass safety and love onto her child, enabling to care of the hygienization, to identify changes and to talk, by facilitating the exercise of the maternity and strengthening the link. ${ }^{7}$

However, the carrying out of the bath in the first days of the baby' $s$ life is regarded as one of the most challenging by the primiparous mothers, condition that might be modified by effective educative actions even in the prenatal, enabling the primiparous woman to give maternal care more safe. ${ }^{8}$

The first bath usually generates many expectancies, leaving the mother apprehensive and, most of the time, unsafe before the baby's movements and reactions during the procedure. ${ }^{9}$ The presence of the umbilical cord stump and the apparent fragility of the newborn also contribute to this insecurity.

It is worth mentioning that the bathing can also produce in the mother several doubts regarding the adequate way of bathing the baby, the correct sequence to be followed the good temperature of water, the bathing frequency, among others. 
In general, the difficulties on handling the baby during the bath occur due to the neonate fragility and the fear that the mother has in holding it. ${ }^{7}$ This insecurity is understandable, since the special care must be adopted each movement of the newborn, that must be handled with delicacy and confidence.

Another important question that merits special attention in the follow-up of pregnant and post-partum women refers to the challenges for the promotion and adherence to breastfeeding, since many barriers are placed by the own lactating woman, relatives, neighbors, among others, being essential for the lactation successful, the orientations repassed by the health professionals. Some aspects such as the incorrect handling, inverted nipples, pain and stress may interfere in the breastfeeding success, contributing to the early weaning, for this reason the primiparous mother requires support and adequate orientation, in order to overcome the difficulties.

It is important that the nurse knows these difficulties and intervenes, in order to the lactation is successful, since possible obstacles faced by women in the breastfeeding may be predictive of weaning. ${ }^{10,11}$

Since the care of the neonate generates many doubts among the mothers, it is necessary that the health professional, mainly the nurse, as an educator for health, is always sensitive to recommend to the mothers, practices of health promotion and prevention of grievances in front of primary health care that they will carry out with their children at home. ${ }^{8}$

On the other hand, when the attention to the child involves the maternal ability and sensitivity to understand the expressions in which the baby transmit its feelings, solicit affection and attention, some difficulties may interfere in the efficacy of the maternal response, as reported by the mothers, regarding the different types of crying of their babies.

It is worthy to emphasize that, in the first months of life, the crying is the main way of babies' communication, being important the physical contact with the mother, her involvement in the essential care and the breastfeeding, so that she can recognize in her child's reactions, the meaning of the most subjective gestures, becoming able to respond to its appeals. The interpretative process undertaken by the mother is always intentional, in finding acceptable explanations to the crying. ${ }^{12}$

The child uses natural signs deprived of intentions or meanings that will become conventional subsequently. The mother as a sign that the baby wishes to communicate something, such as discomfort or suffering, assimilates these forms of non-verbal communication. Thus, the mother will endow the gesture of meaning, which will be apprehended by the baby in the future, which, thus, will start using it intentionally. ${ }^{13}$

However, mostly, to satisfy the baby's needs requires that the mother has skills and knowledge, mainly for some more complex tasks, such as the cleaning of the umbilical cord stump, which must be carried out every day after the bath and the change of diapers, by using aseptic technique, sterile or clean material, in order to keep it always clean and dry, contributing to the infectious disease prevention. According to scholars, the infections in NB during the neonatal period remains one of the main causes of neonatal mortality in the world, of which one high rate of these infections can be derived from the bacterial colonization of the belly, due to the cord stump practices are followed in accordance with cultural traditions within communities and the disparities of these practices worldwide. ${ }^{14}$

In the mothers participants' testimonies, it was observed that these carried out the belly of their children with cotton swab and $70 \%$ alcohol; there have no reports about the use of coverages or foreign objects, did not refer presence of symptoms as hyperemia, secretion or bad smell; it was noticed that some mothers did not know the importance of giving continuity to the hygienization of the umbilical scar, disrupting this procedure soon after the stump fall. However, regardless of the orientation that is given to the primiparous mother during the prenatal period, the information divulged by the nurse must be complete, ensuring adequate maternal understanding of all the process. ${ }^{8}$

The umbilical cord stump cleaning must be done every day after the bath and the changing diapers until the umbilical wound has been completely healed; strips or other covers on the stump should not be used, since these do not bring any benefit and may cause irritation, secretion and bad smell, in addition, it is known that the simple hands' hygienization before and after the referred procedure, is highly effective in preventing infections.

In relation to the change of diaper, although it is a simple procedure and easy to carry out, it requires that the caregiver be willing to frequent changes that must occur always after the eliminations, avoiding the prolonged contact of these with the baby's skin, promoting comfort and preventing rashes and other dermatitis.

The successive practices during care make the procedures increasingly easy to carry out and, consequently, more pleasant. ${ }^{9}$

On the other hand, it believes that, in unavailable of formal orientation, the woman tends to adequate the care in any way she wishes or appears to be appropriate, that may lead to risks to the baby. Some speeches apprehended reveal the unknown of the mothers as to the adequate position enabling the baby to sleep and the difficulty to position it to burp. Such unknown could maybe be justified by the reproduction of care observed in the family scope by older members, such as grandmothers, sisters or female friends, disregarding updated practices and recommended by the Ministry of Health, ${ }^{15}$ by the fact that these recommendations do not achieve the domestic space, therefore, it is believed that all contact established with the individual might be conceived as a moment of promotion to health. ${ }^{16}$

In this sense, health professionals that carry out the prenatal have the role of strengthening the mother for the good care practices of the child, including her in activities of education and health, with updated and safe information. Possible doubts should be clarified in due time and the empowered mother in decision-making about routine of care at home.

The same concern was observed in study about the experience lived by mothers of premature newborns, showing that some mothers take the baby home without being trained to care 
at home. These aspects reinforce the importance of involving the mother in the teaching-learning process, not only as a passive receiving person, but as most of all, as an active subject of the educative process. ${ }^{17}$

It is known that much of the knowledge in the care practice of the baby carried out by the primiparous mothers is due to the experiences lived in family, where it was customary that older daughters cared of younger brothers. Therefore, mothers who experienced such practice feel more comfortable caring of her own child, since the previously acquired knowledge enhance her self-confidence, making them safer.

On the other hand, currently, the internet is increasingly present in the daily lives of persons, and being pointed out by the mothers as an indispensable tool for research on different matters, including those related to health. Therefore, the primiparous mothers make use of this resource to enlighten their doubts regarding the maternal care at home; in the participants 'testimonies, the access to social medias are referred as feasible alternative to obtain fast answers to certain situations involving the care of the baby. It is important to note that, even providing a wide range of information in digital means, some mothers reaffirm their preference for orientations received from their mother, considering these more reliable than those found through new technologies.

It is worth pointing out that many contents launched in social Medias are not true and for this reason, can pose risks to users' health. In this sense, those become important specific researches or interventions, including the public sector, for a better understanding the internet use for health, its advantages and risks. ${ }^{18}$

Thus, all the attention must be given to the primiparous mothers, with relevant guidelines on time, so that they can come to the maternity more safe, with more specific knowledge about the diversity of care, feelings and difficulties that may arise in exercising the new role of mother.

\section{CONCLUSION AN IMPLICATIONS FOR PRACTICE}

The results of this research show feelings of fear, insecurity and difficulties of the primiparous mothers during the exercise of the maternity. At birth, the child needs for attention and care to supervene, which, in most of the time, the mother has never carried out.

However, it was noticed in this study, the readiness of mothers by launching into the care of the child, impelled by the love and caring, in order to play their new role successfully. Thus, the maternal care practice is permeated by feelings that can be alleviated by the own mother's experience, support from relatives and health professionals who should draw attention to the present difficulties, especially in the first days of the mother's cohabitation with the baby, providing them with support and orientations that enable them to carry out a better care of its baby. The study also showed that some care with the baby at home were carried out in an inadequate way. In this sense, the presence of the health team, during the first week of life of the baby, including home visits to the post-partum women, is imperative, to offer the mothers orientations that address their needs at that time.

Other data of this study revealed that the practice of the essential care of the baby at home needs to be more discussed and valued by nurses, since the lack of information has a negative impact on the maternal behavior, as shown regarding the way how the mothers carried out the bath or positioned the child to sleep and suck, among others.

From this research, one intends to implement strategies that enable the access to the puerperal women in the baby's first week of life, in order to reinforce the essential orientations for the care of the newborn (NB). At last, to try to sensitive other members of the health team for the development of actions that contribute with the good performance of the primiparous mothers in providing care of the baby.

Therefore, this research was relevant finding that the primiparous mothers have gaps of knowledge on the maternal care, at the same time highlighting the importance of the nurse's role, in the sense of preparing the mother, so that she feels safer during the exercise of the maternity. In the relation to the limits of this research, it was considered that were minimal and that were more related to the time for conducting the interviews, but in view of the total accessibility of the researcher to the mothers participants and the existence of adequate place, the time was easily adjusted according to the availability of both parties. It also can infer that this study contributed to the teaching, regarding the professional formation of the nursing students, since the research was developed in a health-school institution.

\section{ACKNOWLEDGEMENTS}

To Cristiane Mourão Carvalho de Mesquita, Coordinator of the UAPS Dom Aloísio Lorscheider and to the Nurse Francisco Marcos de Lima Messias, for their valuable contributions to the study.

\section{REFERENCES}

1. Macana EC, Comim F. O papel das práticas e estilos parentais no desenvolvimento da primeira infância. In: Pluciennik GA, Lazzari MC, Chicaro MF, orgs. Fundamentos da família como promotora do desenvolvimento infantil: parentalidade em foco. São Paulo (SP): Fundação Maria Cecília Souto Vidigal; 2015. p. 34-47.

2. Ferreira ACT, Pieszak GM, Rodrigues SO, Ebling S. Consulta de puericultura: desafios e perspectivas para o cuidado de enfermagem à criança e a família. Vivências [Internet]. 2015 May; [cited 2018 Dec 21]; 11(20):231-41. Available from: http://www.reitoria.uri.br/ vivencias/ Numero_020/artigos/pdf/Artigo_19.pdf 
3. Pessôa LF, Seidl-de-Moura ML, Ramos DO, Mendes DMLF. Sistemas de cuidados e o discurso de diferentes cuidadores do Rio de Janeiro: evidências de trajetória de desenvolvimento. Estud Psicol (Campinas) [Internet]. 2016 Mar; [cited 2018 Dec 21]; 33(1):71-82. Available from: http://dx.doi.org/10.1590/1982-02752016000100008

4. Dezoti AP, Alexandre AMC, Tallmann VAB, Maftum MA, Mazza VA. Social networking in support of child development according to the family health team. Esc Anna Nery [Internet]. 2013 Dec; [cited 2018 Dec 21]; 17(4):721-9. Available from: http://dx.doi.org/10.5935/14148145.20130017

5. Minayo MCSO. Desafio do conhecimento: pesquisa qualitativa em saúde. $12^{\mathrm{a}}$ ed. São Paulo (SP): Hucitec; 2010.

6. Simas FB, Souza LV, Scorsolini-Comin F. Significados da gravidez e da maternidade: discursos de primíparas e multíparas. Psicol Teor Prat [Internet]. 2013 Jan/Apr; [cited 2018 Dec 21]; 15(1):19-34. Available from: http://pepsic.bvsalud.org/pdf/ptp/v15n1/02.pdf

7. Silva CMS, Dantas JC, Souza FMLC, Silva RAR, Lopes TRG, Carvalho JBL. Sentimentos vivenciados por puérperas na realização do primeiro banho do recém-nascido no alojamento conjunto. Mundo Saúde [Internet]. $2015 \mathrm{Jul} / \mathrm{Sep}$; [cited $2018 \mathrm{Mar} 22$ ]; 39(3):279-86. Available from: http://bvsms.saude.gov.br/bvs/periodicos/mundo_saude_artigos/ Sentimento_vivenciado_\%20puerperas.pdf. DOI: 10.15343/01047809.20153903279286

8. Lucena DBA, Guedes ATA, Cruz TMAV, Santos NCCB, Collet N, Reichert APS. First week of integral health for the newborn: nursing actions of the Family Health Strategy. Rev Gaúcha Enferm [Internet]. 2018 Aug; [cited 2018 Dec 21]; 39:e2017-0068. Available from: http://dx.doi. org/10.1590/1983-1447.2018.2017-0068

9. Veronez M, Borghesan NAB, Corrêa DAM, Higarashi IH. Experience of mothers of premature babies from birth to discharge: notes of field journals. Rev Gaúcha Enferm [Internet]. 2017 Jul; [cited 2018 Mar 22]; 38(2):e60911. Available from: http://dx.doi.org/10.1590/19831447.2017.02.60911

10. Rocci E, Fernandes RAQ. Dificuldades no aleitamento materno e influência no desmame precoce. Rev Bras Enferm [Internet]. 2014 Jan/Feb; [cited 2018 Mar 22]; 67(1):22-7. Available from: http://dx.doi. org/10.5935/0034-7167.20140002
11. Rocha GP, Oliveira MCF, Ávila LBB, Longo GZ, Cotta RMM, Araújo RMA. Condicionantes da amamentação exclusiva na perspectiva materna. Cad Saúde Pública [Internet]. 2018 Sep; [cited 2018 Dec 21]; 34(6):e00045217. Available from: http://dx.doi.org/10.1590/0102$311 \times 00045217$

12. Goretti ACS, Almeida SFC, Legnani VN. A relação mãe-bebê na estimulação precoce: um olhar psicanalítico. Estilos Clin [Internet] 2014; [cited 2018 Dec 21]; 19(3):414-35. Available from: https://dx.doi. org/10.11606/issn.1981-1624.v19i3p414-435

13. Camargo JF, Salomão NMR, Aquino FSB, Nunes LL. Os gestos na comunicação mãe-bebê: um estudo longitudinal. Estud Pesqui Psicol [Internet]. 2015 Jul; [cited 2018 Dec 26]; 15(2):652-70. Available from: http://pepsic.bvsalud.org/scielo.php?script=sci_arttext\&pid $=$ S1808-42812015000200012

14. Stewart D, Benitz W. Committee on Fetus and Newborn. Umbilical cord care in the newborn infant. Pediatrics [Internet]. 2016 Sep; [cited 2018 Dec 21]; 138(3):e20162149. Available from: http://pediatrics. aappublications.org/content/pediatrics/138/3/e20162149.full.pdf. DOI: 10.1542/peds.2016-2149

15. Ministério da Saúde (BR). Secretaria de Atenção à Saúde. Departamento de Atenção Básica. Saúde da criança: crescimento e desenvolvimento. Brasília (DF): Ministério da Saúde; 2012.

16. Pereira MM, Penha TP, Vaz EMC, Collet N, Reichert APS. Conceptions and practices of professional family health strategy for health education Texto Contexto Enferm [Internet]. 2014 Jan/Mar; [cited 2018 Mar 22]; 23(1):167-75. Available from: http://dx.doi.org/10.1590/S010407072014000100020

17. Frota MA, Silva PFR, Moraes SR, Martins EMCS, Chaves EMC Silva CAB. Alta hospitalar e o cuidado do recém-nascido prematuro no domicílio: vivência materna. Esc Anna Nery [Internet]. 2013 Apr/ Jun; [cited 2018 Dec 21]; 17(2):277-83. Available from: http://dx.doi. org/10.1590/S1414-81452013000200011

18. Moretti FA, Oliveira VE, Silva EMK. Access to health information on the internet: a public health issue? Rev Assoc Med Bras [Internet]. 2012 Nov/ Dec; [cited 2018 Mar 22]; 58(6):650-8. Available from: http://www.scielo. br/pdf/ramb/v58n6/en_v58n6a08.pdf. DOI: http://dx.doi.org/10.1590/ S0104-4230201200060000 